\title{
Glutamate Receptor Targeting to Synaptic Populations on Purkinje Cells Is Developmentally Regulated
}

\author{
Hui-Min Zhao, Robert J. Wenthold, and Ronald S. Petralia \\ National Institute on Deafness and Other Communication Disorders/National Institutes of Health, \\ Bethesda, Maryland 20892
}

\begin{abstract}
Selective targeting of neurotransmitter receptors to specific synapse populations occurs in adult neurons, but little is known about the development of these receptor distribution patterns. In this study, we demonstrate that a specific developmental switch occurs in the targeting of a receptor to an identified synapse population. Localization of delta and AMPA glutamate receptors at parallel and climbing fiber synapses on the developing Purkinje cells was studied using postembedding immunogold. Delta receptors were found to be abundant on postsynaptic membranes at parallel fiber synapses from postnatal day 10 (P10) to adult. In contrast, delta receptors were found to be high at climbing fiber synapses only at P10 and P14. Thus, a major finding of this paper is that high levels of delta receptors are transiently expressed in climbing fiber synapses in the second postnatal week. Labeling of synapses with anti-delta
\end{abstract}

Glutamate receptors, including AMPA, kainate, delta, NMDA, and metabotropic types, are found in the developing cerebellum and may play roles in the early formation of Purkinje cell synapses (e.g., Bettler et al., 1990; Pellegrini-Giampietro et al., 1991; Rabacchi et al., 1992; Bahn et al., 1994; Laurie and Seeburg, 1994; Yuzaki et al., 1996; Kano et al., 1997; Levenes et al., 1997). In adults, a complex pattern of afferent innervation is associated with an abundance of glutamate receptor subtypes and subunits that often sort to different synaptic populations on Purkinje cells and other neurons (Martin et al., 1993; Baude et al., 1994; Petralia et al., 1994; Siegel et al., 1994; Landsend et al., 1997; Rubio and Wenthold, 1997; Z hao et al., 1997). However, it is not clear how such arrangements of receptors develop and are maintained. The pattern seen in adults may be established during initial synaptogenesis or originate during synapse maturation, perhaps because of changes in synaptic activity.

Purkinje cells have two kinds of excitatory synapses (formed by parallel and climbing fibers) that develop in early postnatal animals and, at least in adults, are arranged and interact in ways affecting the plasticity of Purkinje cell responses and motor coordination (Linden, 1994; Llinás and Walton, 1998). Selective targeting of glutamate receptors has been established for adult

Received Feb. 26, 1998; revised April 29, 1998; accepted April 30, 1998.

This study was supported by the National Institute on Deafness and Other Communication Disorders Intramural Research Program. We thank Drs. O. P. Ottersen, M. E. Rubio, and Y.-X. Wang for technical advice and for reviewing this manuscript and Drs. K.-H. Huh, S. Safieddine, and S. L. Sullivan for reviewing this manuscript.

Correspondence should be addressed to Dr. Ronald S. Petralia, National Institute on Deafness and Other Communication Disorders/National Institutes of Health, 36/5D08, 36 Convent Drive, MSC 4162, Bethesda, MD 20892-4162.

Copyright (C) 1998 Society for Neuroscience $0270-6474 / 98 / 185517-12 \$ 05.00 / 0$ receptor antibody at P10 was limited to the postsynaptic membrane of excitatory synapses and was absent from GABAergic synapses. Unlike delta receptor immunolabeling, AMPA receptor immunolabeling (GluR2/3 and GluR2 antibodies) was high in the postsynaptic membranes of synapses at early postnatal ages (P2 and P5) and was higher in climbing fiber synapses than in parallel fiber synapses from P10 to adult. The present study shows that synapse-specific targeting of glutamate receptors in Purkinje cells is developmentally regulated, with the postsynaptic receptor composition established during synapse maturation. This composition is not dependent on the nature of the initial establishment of synaptic connections.

Key words: AMPA; cerebellum; climbing fiber; delta; parallel fiber; synaptogenesis

Purkinje cells; delta 2 receptors are high at parallel fiber synapses but low at climbing fiber synapses (Landsend et al., 1997; Z hao et al., 1997). The development of excitatory synaptic connections with Purkinje cells begins shortly after birth (for review, see Altman and Bayer, 1997). Functional climbing fiber synapses are found on Purkinje cells from postnatal day 2 (P2), and multiple innervation of a Purkinje cell by climbing fibers is found by P3 (Crépel et al., 1981). Parallel fiber synapse formation begins at approximately P7 (with possible rare exceptions). Inhibitory synapses do not form on Purkinje cells before this time. Thus, this first stage $(\sim \mathrm{P} 2-\mathrm{P} 5)$ of Purkinje cell innervation results in the formation of synapses from multiple climbing fibers contacting somatic processes of Purkinje cells. The second stage $(\sim \mathrm{P} 10-$ P14) includes (1) outgrowth of the Purkinje cell-dendrite arborization, (2) multiple innervation of these dendrites by parallel fiber-dendrite spine synapses, and (3) formation of climbing fiber-Purkinje dendrite spine synapses, with loss of climbing fiber-Purkinje somal synapses and reduction to one climbing fiber per Purkinje cell by approximately P15 in most cases (Crépel et al., 1981; Mariani and Changeux, 1981). The final stage ( P21adult) involves final maturation of excitatory synapses on Purkinje cells; adult Purkinje cells are innervated by many parallel fibers plus numerous synaptic contacts from one climbing fiber.

The present study uses the Purkinje cell as a model system to examine how glutamate receptor targeting may be developmentally regulated and to determine when the adult receptor pattern is established. These questions are explored by studying the development of delta and AMPA receptors at parallel and climbing fiber synapses on Purkinje cells using postembedding immunogold. Although several kinds of glutamate receptors are found in developing and adult parallel and climbing fiber synapses, the 
present study concentrates on AMPA and delta receptors because their distributions at adult Purkinje cell synapses have been well characterized and differential distribution of delta receptors has been shown in adult Purkinje cells (Landsend et al., 1997; Zhao et al., 1997).

\section{MATERIALS AND METHODS}

Antibodies. Antibody production, purification, and characterization have been described previously (Wenthold et al., 1992; Mayat et al., 1995; Petralia et al., 1997). GluR2/3 antibody also is referred to as GluR2/3/4c because it recognizes the variant GluR4c (Gallo et al., 1992). These antibodies have been used in a number of immunogold studies (Phend et al., 1995; Matsubara et al., 1996; Popratiloff et al., 1996; Petralia et al., 1997; Rubio and Wenthold, 1997; Nusser et al., 1998; Wang et al., 1998), including descriptions of labeling in parallel and climbing fiber synapses in adults (Nusser et al., 1994; Landsend et al., 1997).

Postembedding immunogold. The technique used in the present study has been described (Petralia et al., 1997; Rubio and Wenthold, 1997; Wenthold et al., 1997; Petralia and Wenthold, 1998; Wang et al., 1998) and is a modification of a technique published previously (Matsubara et al., 1996; Landsend et al., 1997). Male Sprague Dawley rats were anesthetized and perfused transcardially $(10 \mathrm{~min}$ for adults; $5 \mathrm{~min}$ for juveniles) as described previously (Petralia and Wenthold, 1992; Petralia et al., 1994, 1997; Z hao et al., 1997). Animals weighed as follows: adults, 151 and 156 gm; P21, 48 and 51 gm; P14, 26 and 26 gm; P10, 19 and 21 gm; P5, 12 and $15 \mathrm{gm}$; and P2, 7 and $8 \mathrm{gm}$. The fixative used was $4 \%$ paraformaldehyde plus $0.5 \%$ glutaraldehyde in $0.12 \mathrm{M}$ phosphate buffer, $\mathrm{pH}$ 7.2-7.3. Brains were removed, fixed, washed, and sectioned with a vibratome (Pelco DTK-3000W microslicer). Washing and vibratomy were performed in phosphate buffer $(0.1 \mathrm{M}$ with $4 \%$ glucose $)$; then tissue (200 $\mu \mathrm{m}$ parasagittal sections) was cryoprotected using a series of 10, 20, and 30\% glycerol (last step overnight) in $0.1 \mathrm{M}$ phosphate buffer and was plunge-frozen in liquid propane in a Leica EM CPC. Frozen tissue was immersed in $1.5 \%$ uranyl acetate in methanol at $-90^{\circ} \mathrm{C}$ in a Leica AFS freeze-substitution instrument, infiltrated in Lowicryl HM 20 resin at $-45^{\circ} \mathrm{C}$, and polymerized with UV light $\left(-45\right.$ to $\left.0^{\circ} \mathrm{C}\right)$. Thin sections were cut on a Leica Reichert Ultracut S ultramicrotome and collected on nickel grids (Electron Microscopy Sciences, Fort Washington, PA).

Thin sections on grids were incubated in $0.1 \%$ sodium borohydride + $50 \mathrm{~mm}$ glycine in Tris-buffered saline and $0.1 \%$ Triton X-100 (TBST) for $10 \mathrm{~min}$. Grids were incubated in blocking serum in TBST for $10 \mathrm{~min}$ [plus $10 \%$ normal goat serum (NGS)]. Then grids were incubated in primary antibody in NGS/TBST for $2 \mathrm{hr}$, followed by washes in TBST, blocking in NGS/TBST, and incubation in 1:20 immunogold in NGS/TBST plus $0.5 \%$ polyethylene glycol (20,000 molecular weight). Ten nanometer immunogold particles (Amersham, Arlington Heights, IL) were used for single labeling, and 10 and $30 \mathrm{~nm}$ particles $(30 \mathrm{~nm}$ gold, used for GABA localization, from Goldmark, Phillipsburg, NJ) were used for double labeling. For double labeling (two animals), immunolabeling first was completed for delta $1 / 2$ antibody using a $10 \mathrm{~nm}$ gold-conjugate; then sections were kept at $80^{\circ} \mathrm{C}$ for $1 \mathrm{hr}$ in a chamber containing $3 \mathrm{gm}$ of paraformaldehyde (Wang and Larsson, 1985; Matsubara et al., 1996; Landsend et al., 1997), followed by washing in water and TBST, incuba- tion in $1 \%$ normal goat serum in TBST, and incubation with GABA polyclonal antibody [1:100; characterized in Wenthold et al. (1986)] in $1 \%$ NGS/TBST; further steps were done as outlined above (except that serum was used always at $1 \%$ ). After washes, sections were dried and stained with $1 \%$ uranyl acetate and $0.3 \%$ lead citrate.

Concentrations of primary antibodies (GluR1, $4.1 \mu \mathrm{g} / \mathrm{ml}$; GluR2, 4 $\mu \mathrm{g} / \mathrm{ml}$; GluR2 $/ 3,1.3 \mu \mathrm{g} / \mathrm{ml}$; delta $1 / 2,0.7 \mu \mathrm{g} / \mathrm{ml}$ ) were selected to produce little or no background immunogold labeling. Such background artifactual staining was examined in both control sections and within the experimental sections, in structures that are presumed not to contain glutamate receptors. Immunogold-labeled sections were considered acceptable if they showed little or no labeling inside the mitochondria and nucleus.

Areas surveyed. Sections were taken from the same region of the cerebellum (folia III-V) for all ages to eliminate variations attributable to regional differences in cerebellar structure and function and to differences in the timing of ontogenesis; i.e., posterior folia develop more rapidly than anterior ones in early postnatal times, and this can affect the level of glutamate receptor expression (Takayama et al., 1996).

Parallel and climbing fiber synapses were identified by established criteria (Mugnaini, 1972; Palay and Chan-Palay, 1974; Altman and Bayer, 1997) as noted previously (Zhao et al., 1997). All synapses in the Purkinje cell layer were included for P2 and P5 to get an adequate count, because synapses are very uncommon at these ages. It is likely that all or nearly all of these synapses originate from climbing fibers; any other kind of Purkinje afferent synapse is either very rare or not present at these ages (Altman and Bayer, 1997). Altman and Bayer (1997) suggest that climbing fibers also can form synapses on Golgi cells adjacent to Purkinje cells at P5, but no synapses associated with putative Golgi cells, as described by Altman and Bayer (1997), were photographed in the present study.

Thin sections were examined from one block from each of two animals at each age (P2, P5, P10, P14, P21, and adult) for each antibody (GluR2, GluR2/3, and delta 1/2; only P2, P10, and adult for GluR1). All identified climbing fiber synapses were included in counts, because these synapses are uncommon. Parallel fiber synapses were sampled by selecting an area in the middle of the molecular layer and counting all parallel fiber synapses.

Immunogold counts at synapses included all gold particles found in the synaptic cleft and postsynaptic density (Rubio and Wenthold, 1997; Wang et al., 1998). Synapse measurements were taken on $50,000 \times$ prints. Because these synapses tend to be highly curved, measurements of postsynaptic membrane/density lengths were done by tracing them on a Summagraphics tablet and analyzing them with the Neurolucida image analysis system (Microbrightfield, Colchester, VT). Statistical analyses ( $t$ test, two sample assuming unequal variances) were done using $\mathrm{Mi}$ crosoft Excel (4.0). Statistical significance $(p<0.01)$ was tested for the number of gold particles per micrometer of postsynaptic density for each antibody (delta 1/2, GluR2/3, and GluR2). GluR1 labeling was studied qualitatively only. The number of gold particles per micrometer of postsynaptic density was calculated by taking the sum of the individual values of the number of gold particles per micrometer of postsynaptic density per synapse and dividing by the number of synapses (Rubio and Wenthold, 1997; Wang et al., 1998). All identified synapses were counted,

Table 1. The comparison of distribution of delta receptor at different ages of the cerebellum

\begin{tabular}{|c|c|c|c|c|c|}
\hline & & $\begin{array}{l}\text { Number of } \\
\text { synapses }\end{array}$ & $\begin{array}{l}\text { Average length of } \mathrm{PSD}^{a} \\
(\mathrm{M} \pm \mathrm{SE})\end{array}$ & $\begin{array}{l}\text { Average number of } \\
\text { gold/synapse (range) }\end{array}$ & $\begin{array}{l}\text { Number of gold } / \mu \mathrm{m} \\
(\mathrm{M} \pm \mathrm{SE})\end{array}$ \\
\hline $2 \mathrm{~d}$ & $\mathrm{CF}$ & 62 & $0.29 \pm 0.01$ & $0.24(0-2)$ & $1.0 \pm 0.35$ \\
\hline $5 \mathrm{~d}$ & $\mathrm{CF}$ & 36 & $0.27 \pm 0.02$ & $0.61(0-4)$ & $2.60 \pm 0.84$ \\
\hline \multirow{2}{*}{$10 \mathrm{~d}$} & $\mathrm{PF}$ & 31 & $0.28 \pm 0.02$ & $5.52(1-17)$ & $21.23 \pm 3.08$ \\
\hline & $\mathrm{CF}$ & 46 & $0.33 \pm 0.02$ & $3.35(0-9)$ & $11.70 \pm 1.57$ \\
\hline \multirow{2}{*}{$14 \mathrm{~d}$} & $\mathrm{PF}$ & 40 & $0.29 \pm 0.01$ & $6.10(1-12)$ & $20.13 \pm 1.23$ \\
\hline & $\mathrm{CF}$ & 52 & $0.38 \pm 0.02$ & $5.40(0-16)$ & $15.34 \pm 1.16$ \\
\hline \multirow{2}{*}{$21 \mathrm{~d}$} & $\mathrm{PF}$ & 74 & $0.27 \pm 0.01$ & $6.76(0-19)$ & $25.24 \pm 1.20$ \\
\hline & $\mathrm{CF}$ & 31 & $0.27 \pm 0.02$ & $0.42(0-2)$ & $1.84 \pm 0.50$ \\
\hline \multirow{2}{*}{ Adult } & $\mathrm{PF}$ & 109 & $0.32 \pm 0.01$ & $8.27(1-19)$ & $26.06 \pm 0.92$ \\
\hline & $\mathrm{CF}$ & 28 & $0.32 \pm 0.02$ & $0.46(0-3)$ & $1.53 \pm 0.41$ \\
\hline
\end{tabular}

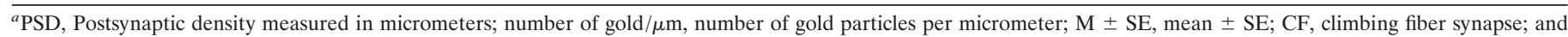
$\mathrm{PF}$, parallel fiber synapse. The increase in number of gold $/ \mu \mathrm{m}$ for CFs from P5 to P10 and the subsequent decrease from P14 to P21 were statistically significant $(p<0.01)$. 

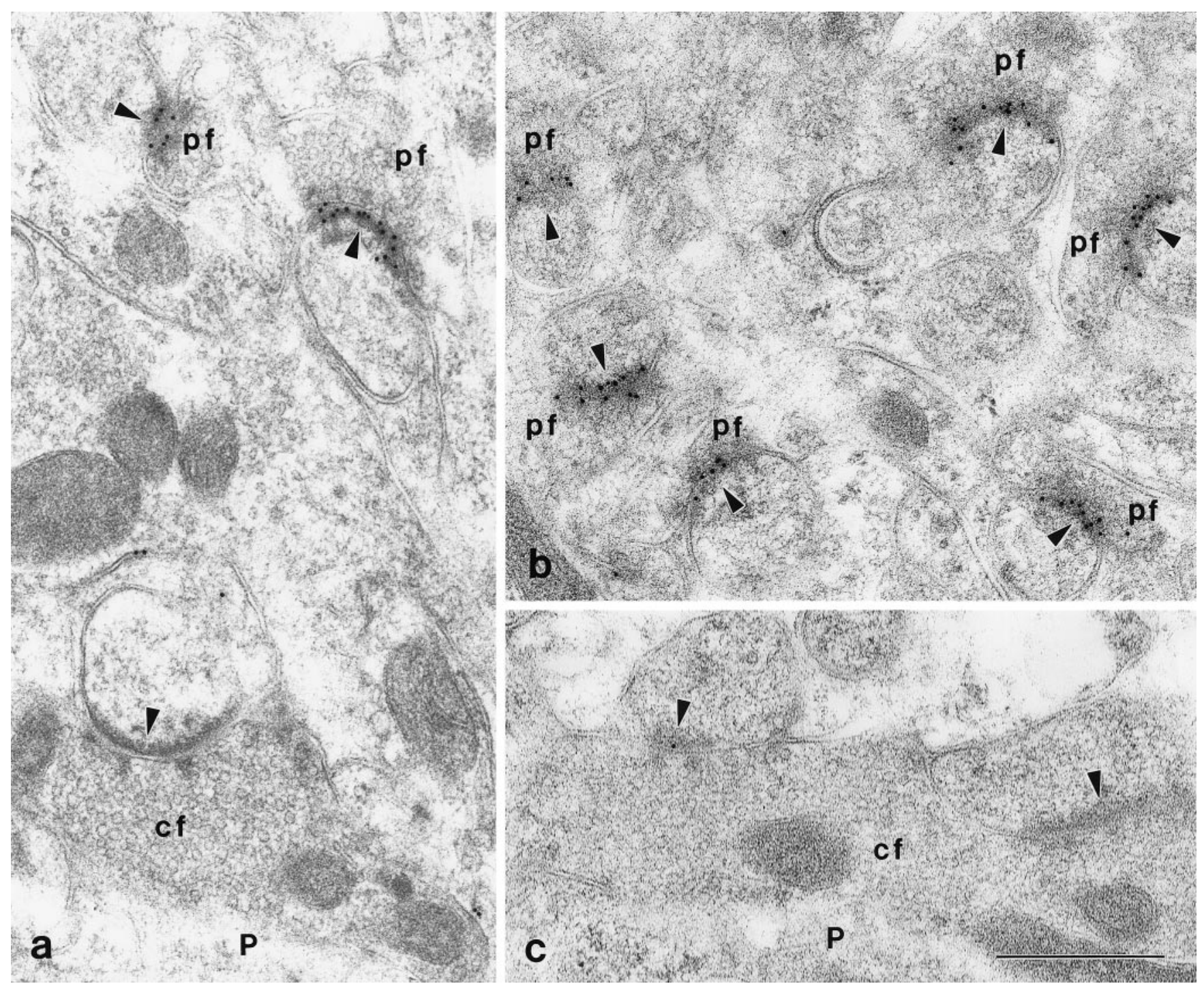

Figure 1. Immunogold labeling (10 nm gold) for delta $1 / 2$ in the adult $(a)$ and $\mathrm{P} 21(b, c)$ cerebellum. Note the abundant labeling of parallel fiber $(p f)$ synapses and the low level or absence at climbing fiber $(c f)$ synapses. Arrowheads indicate the postsynaptic densities/membranes (found on the heads of spines). $P$, Purkinje cell dendrite. Scale bar, $0.5 \mu \mathrm{m}$.

including those that had no gold; a previous study (Nusser et al., 1994) quantified immunogold labeling for GluR2/3 in parallel fiber synapses but excluded synapses with no gold particles and thus is not directly comparable with the present study. An additional study was done on immunolabeling of climbing fiber synapses on dendrites versus cell bodies; counts were compared at P10 and P14 using antibodies to delta $1 / 2$ and GluR2/3. In this case, counts of gold particles found in those climbing fiber synapses included with the main counting study (described above) were combined with counts from additional climbing fiber synapses and presented as a single average number of gold particles per synapse.

Controls. NGS/TBST was substituted for the primary antibody in sections from all six ages for both animals. For double-labeling studies, $1 \%$ NGS/TBST was used instead of GABA antibody for the second antibody run on some sections from both animals.

\section{RESULTS}

\section{Delta 1/2}

Immunogold labeling of synapses for delta $1 / 2$ (Table 1; Figs. 1, 2, 3,4 ) was low at P2 and P5, with an average of less than one gold particle per synapse; presumably all synapses are from climbing fibers at these ages, as explained in Materials and Methods. At
P10 and P14, immunogold labeling of parallel fiber synapses was high and increased only slightly by P21 and in adults. In contrast, immunogold labeling of climbing fiber synapses was high at P10 and P14 but was low at P21 and in adults.

Because delta receptor immunolabeling was high in parallel fiber synapses at all ages but high in climbing fiber synapses only at $\mathrm{P} 10$ and $\mathrm{P} 14$, it is possible that delta receptors lack selective targeting mechanisms at these ages and are high in the postsynaptic membrane of all excitatory and inhibitory synapses. However, in a double immunogold-labeling study, delta receptor immunolabeling was absent from GABAergic synapses at P10 (Fig. 4); it also was absent from similar synapses seen at P14 (although GABA immunolabeling was not done at this age). Moreover, the high density of immunolabeling for delta receptors at both parallel and climbing fiber synapses at P10 and P14 was found only at synapses (parallel and climbing) on dendrites. This comparison of climbing fiber synapses on somata and dendrites was done in addition to the main study presented in the tables, as described in Materials and Methods. Climbing fiber-somal synapses typically 

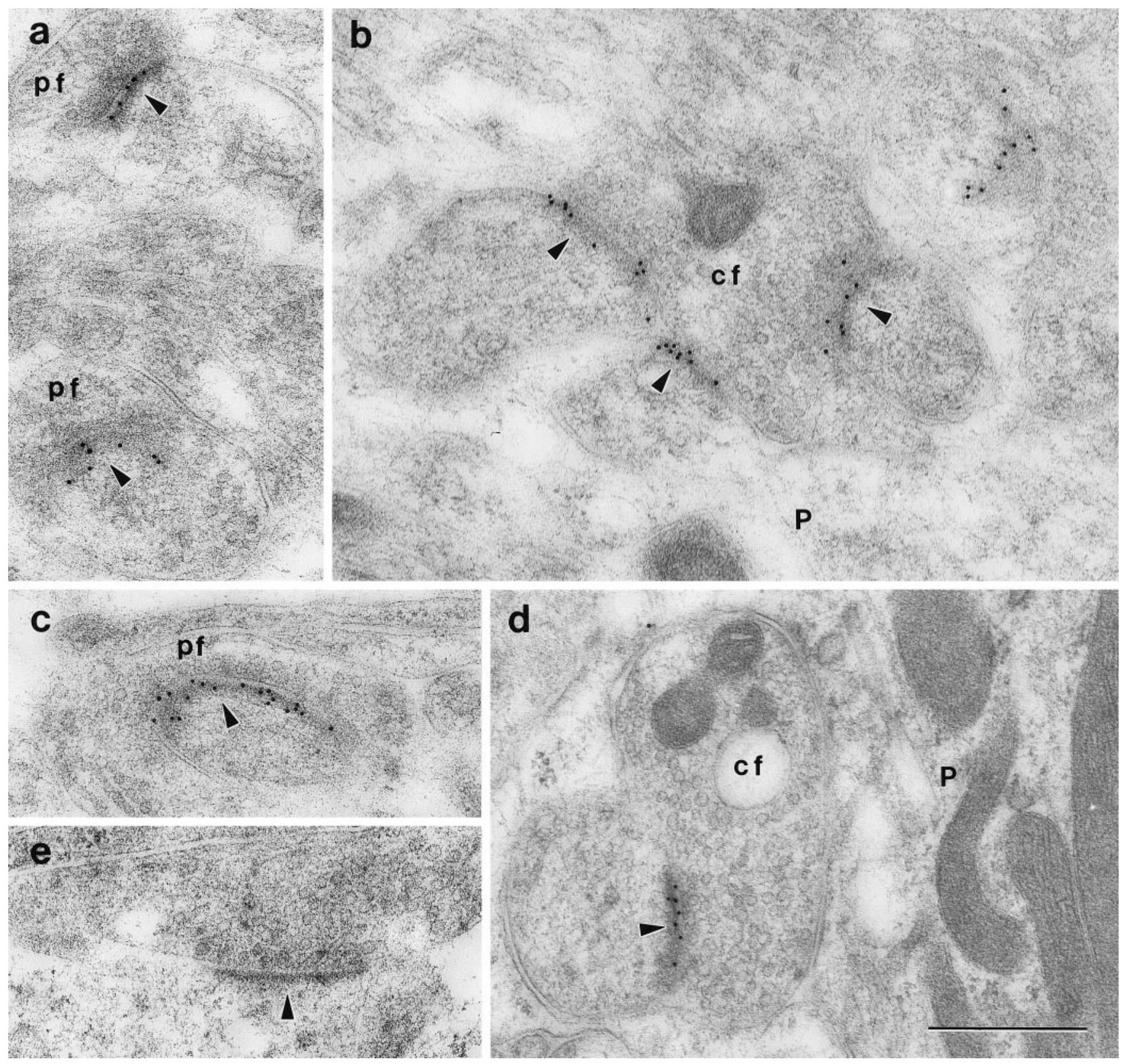

Figure 2. Immunogold labeling for delta $1 / 2$ at $\mathrm{P} 14(a, b), \mathrm{P} 10(c, d)$, and $\mathrm{P} 2(e)$. Both parallel fiber $(p f)$ and climbing fiber $(c f)$ synapses show abundant gold labeling at P10 and P14 in contrast to that seen at P21 and in the adult. Arrowheads indicate the postsynaptic densities/membranes. P, Purkinje cell dendrite. Scale bar, $0.5 \mu \mathrm{m}$.

had low to moderate levels of delta receptor immunolabeling at P10 and P14 (climbing fiber-somal synapses were not found at $\mathrm{P} 21$ or in adults). Thus, at P10, there was an average of 5.6 gold particles/synapse $(n=40)$ for dendrite-climbing fiber synapses versus an average of 0.5 gold particles/synapse $(n=33)$ for somal-climbing fiber synapses; at P14, there was an average of 7.2 gold particles/synapse $(n=59)$ for dendrite-climbing fiber synapses versus an average of 0.8 gold particles/synapse $(n=28)$ for somal-climbing fiber synapses. Note that each of these pairs of values for number of gold particles/synapse would have a mean value approximately similar to the number of gold particles/ climbing fiber synapse shown in Table 1 (in which the soma vs dendrite localization of the synapse was not examined).

\section{GluR2/3}

Immunolabeling with GluR2/3 antibody was highest in synapses at P2 and at climbing fiber synapses at P21 and in adults (Table 2; Figs. 3,5 ). In contrast, immunolabeling was low to moderate in parallel fiber synapses at all ages and lowest in adult parallel fiber synapses.

This labeling pattern was characterized further to determine whether any pattern of differential distribution was present among the climbing or parallel fiber synapses. First, possible differences between somal-and dendrite-climbing fiber synapses were examined during development. Unlike the findings for delta receptor immunolabeling at P10 and P14, no distinctive difference was seen in immunolabeling between climbing fiber syn- 

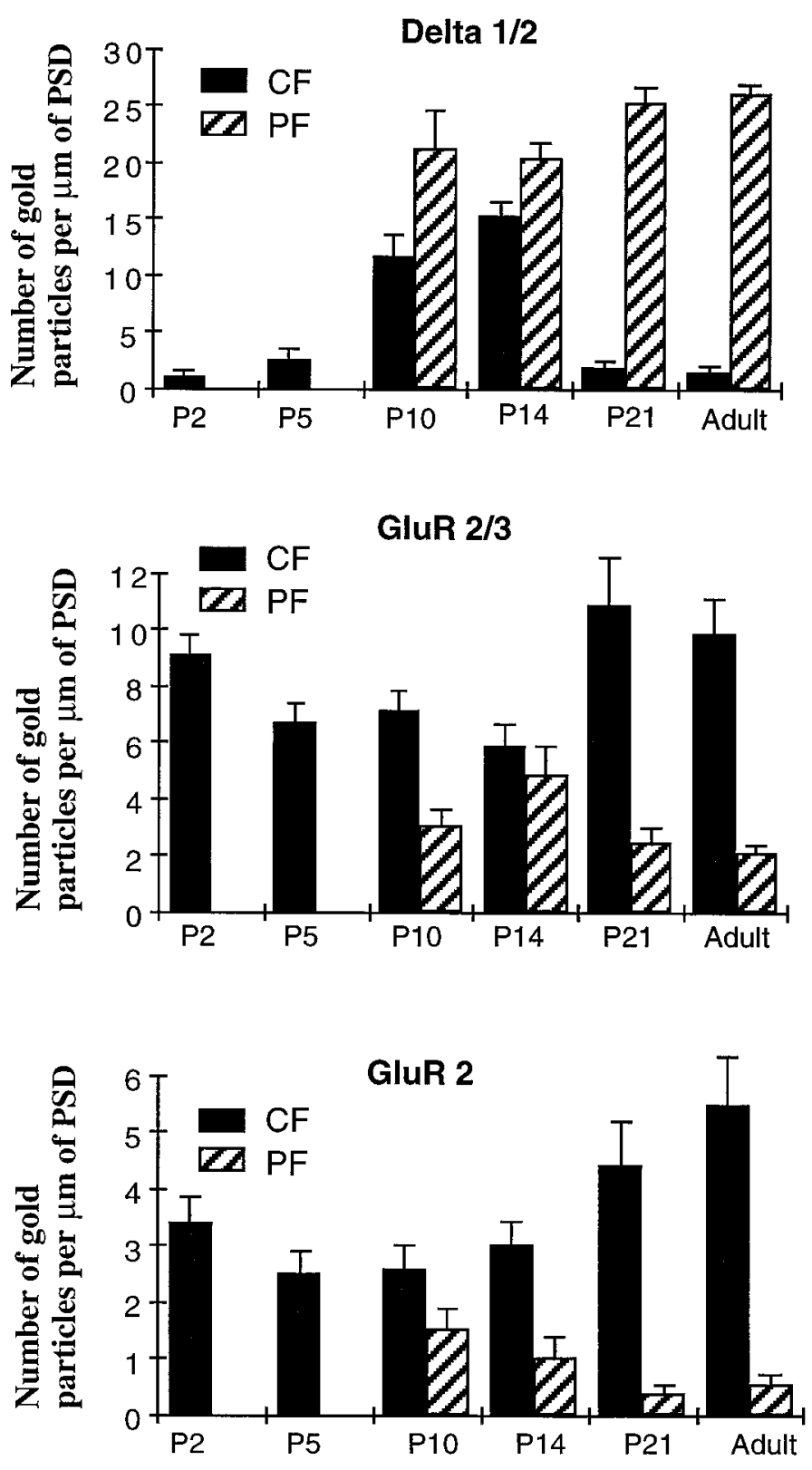

Figure 3. Histograms illustrating the changes in immunogold labeling for delta 1/2 (top), GluR2/3 (middle), and GluR2 (bottom) in the postsynaptic density/membrane $(P S D)$ of parallel fiber $(P F)$ and climbing fiber $(C F)$ synapses on Purkinje cells during development of the cerebellum. Note especially the large differences in the pattern of immunolabeling between delta 1/2 and GluR2/3 and GluR2 at P2-P5 and P21-adult. Lower levels of immunogold labeling for $C F$ versus $P F$ (delta $1 / 2$ ) or for $P F$ versus $C F$ (GluR2/3; GluR2) were statistically significant $(p<0.01)$ at P10 (GluR2/3 only), at P14 (GluR2 only), and at P21 and in adults for all three antibodies. For delta 1/2, statistical significance also was found for the following: P5 $C F$ versus P10 $C F, \mathrm{P} 14 C F$ versus either $\mathrm{P} 21$ or adult $C F$, and $\mathrm{P} 14 P F$ versus $\mathrm{P} 21 P F$.

apses of the soma and dendrites (no climbing fiber-somal synapses were found in adults, and only one was found at P21; Fig. $5 d$ ). Thus, at P10, there was an average of 2.8 gold particles/ synapse $(n=28)$ for dendrite-climbing fiber synapses versus an average of 2.9 gold particles/synapse $(n=60)$ for somal-climbing fiber synapses; at P14, there was an average of 3.1 gold particles/ synapse $(n=24)$ for dendrite-climbing fiber synapses versus an average of 2.7 gold particles/synapse $(n=29)$ for somal-climbing fiber synapses. Second, the low density of immunolabeling in parallel fiber synapses might reflect a sampling bias, because micrographs of parallel fiber synapses were taken from the middle of the molecular layer only. However, in adults, comparison of GluR2/3 immunolabeling of parallel fiber synapses from the lower $2 / 5(n=80)$, middle $2 / 5(n=77)$, and upper $1 / 5(n=60$; sampling method based on demarcation of molecular layer portions by grid holes) of the molecular layer showed no difference in density for the lower two portions and only a slight difference in density for the upper $1 / 5$ portion ( $\sim 25 \%$ lower; data not shown).

\section{GluR2}

The pattern of immunolabeling for GluR2 was similar overall to the pattern seen for GluR2/3, although the density of the immunogold labeling was relatively low (Table 3; Figs. 3, 6). Immunolabeling with GluR2 antibody was moderate in synapses at P2 and reached the highest levels in climbing fiber synapses at P21 and in the adult. In contrast, immunolabeling was low in parallel fiber synapses at P10 and P14 and lowest in P21 and adult parallel fiber synapses.

\section{GluR1}

Assessment of GluR1 immunolabeling at P2, P10, and in the adult showed that immunogold labeling is most abundant in both parallel and climbing fiber synapses at P10 (Fig. 7).

\section{Controls}

All control sections were negative. Gold particles were not found in synapses and were absent or rare in other structures. Control sections for double labeling showed levels and distributions of 10 nm gold particles for delta receptors similar to those on the experimental sections, but $30 \mathrm{~nm}$ gold particles for GABA were absent or rare.

\section{DISCUSSION}

The present study shows that synapse-specific targeting of glutamate receptors in Purkinje cells is developmentally regulated, with the postsynaptic receptor composition established during synapse maturation. This is illustrated dramatically for the delta $1 / 2$ immunolabeling that shows very different distributions between climbing and parallel fiber synapses at various stages of development (Fig. 8). Delta receptor immunolabeling is low in the earliest synapses, i.e., climbing fiber synapses that form on the Purkinje cell soma in the first postnatal week and remain through the second week. Delta receptor immunolabeling is abundant in both climbing and parallel fiber synapses on dendrites in the second postnatal week, when the adult pattern of synapses is established yet is absent from GABAergic synapses. In the adult, delta receptor immunolabeling remains high only at parallel fiber synapses. The AMPA receptors showed a less striking developmental change; GluR2 and GluR3 subunits are generally high in climbing fiber synapses at all ages and somewhat lower in parallel fiber synapses.

The reason why such a distinctive differential distribution of delta receptors is established in adult Purkinje cell synapses is not clear but most likely is related to Purkinje cell plasticity, which involves a Purkinje cell-specific form of long-term depression of parallel fiber synapses (Linden, 1994). Using a thin slice whole-cell patch-clamp technique, Kashiwabuchi et al. (1995) showed that long-term depression is impaired in delta 2 knock-out mice and suggest that delta receptors are linked specifically with long-term depression of adult parallel fiber synapses; this would explain the 


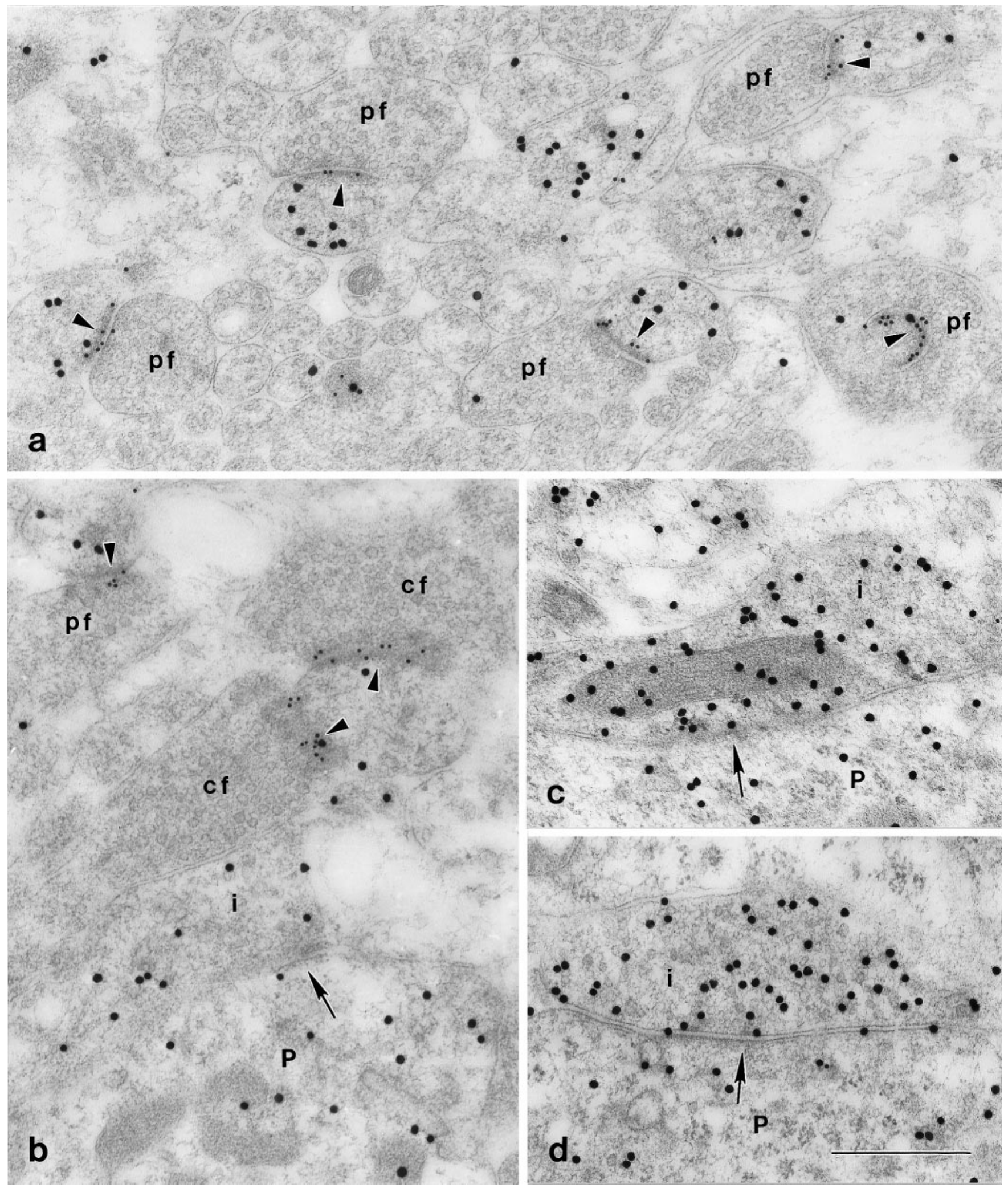

Figure 4. Colocalization of GABA (30 nm gold) neurotransmitter and delta $1 / 2$ receptors (10 nm gold) at P10. Note the absence of GABA labeling in parallel fiber $(p f ; a, b)$ and climbing fiber $(c f ; b)$ terminals and the abundant labeling for GABA in Purkinje cell dendrites $(P ; b)$ and somata $(P ; c, d)$ and in pleomorphic vesicle-containing synaptic terminals $(i)$. Delta receptor labeling is abundant in the postsynaptic density/membrane of parallel and climbing fiber synapses (arrowheads) but is absent from GABAergic synapses (arrows). Scale bar, $0.5 \mu \mathrm{m}$. 


\begin{tabular}{|c|c|c|c|c|c|}
\hline & & $\begin{array}{l}\text { Number of } \\
\text { synapses }\end{array}$ & $\begin{array}{l}\text { Average length of } \mathrm{PSD}^{a} \\
(\mathrm{M} \pm \mathrm{SE})\end{array}$ & $\begin{array}{l}\text { Average number of } \\
\text { gold/synapse (range) }\end{array}$ & $\begin{array}{l}\text { Number of gold } / \mu \mathrm{m} \\
(\mathrm{M} \pm \mathrm{SE})\end{array}$ \\
\hline $2 \mathrm{~d}$ & $\mathrm{CF}$ & 89 & $0.28 \pm 0.01$ & $2.60(0-8)$ & $9.05 \pm 0.70$ \\
\hline $5 \mathrm{~d}$ & $\mathrm{CF}$ & 73 & $0.31 \pm 0.01$ & $1.99(0-7)$ & $6.69 \pm 0.73$ \\
\hline \multirow{2}{*}{$10 \mathrm{~d}$} & $\mathrm{PF}$ & 38 & $0.29 \pm 0.02$ & $0.84(0-4)$ & $3.05 \pm 0.52$ \\
\hline & $\mathrm{CF}$ & 54 & $0.34 \pm 0.01$ & $2.5(0-7)$ & $7.15 \pm 0.66$ \\
\hline \multirow{2}{*}{$14 \mathrm{~d}$} & $\mathrm{PF}$ & 29 & $0.31 \pm 0.02$ & $1.41(0-5)$ & $4.68 \pm 1.05$ \\
\hline & $\mathrm{CF}$ & 29 & $0.43 \pm 0.02$ & $2.45(0-5)$ & $5.88 \pm 0.75$ \\
\hline \multirow{2}{*}{$21 \mathrm{~d}$} & $\mathrm{PF}$ & 61 & $0.29 \pm 0.01$ & $0.74(0-8)$ & $2.44 \pm 0.52$ \\
\hline & $\mathrm{CF}$ & 24 & $0.27 \pm 0.01$ & $3.0(0-8)$ & $10.83 \pm 1.64$ \\
\hline \multirow{2}{*}{ Adult } & $\mathrm{PF}$ & 162 & $0.31 \pm 0.01$ & $0.67(0-6)$ & $2.07 \pm 0.28$ \\
\hline & $\mathrm{CF}$ & 24 & $0.29 \pm 0.02$ & $2.88(0-7)$ & $9.81 \pm 1.16$ \\
\hline
\end{tabular}

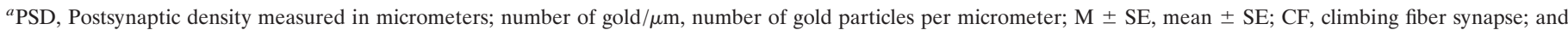
$\mathrm{PF}$, parallel fiber synapse.

The lower number of gold $/ \mu \mathrm{m}$ at $\mathrm{PFs}$ versus CFs at P10, P21, and adult was statistically significant $(\mathrm{P}<0.01)$.

preferential abundance of delta receptor immunolabeling at these synapses. The actual role of delta receptors in parallel fiber longterm depression is unknown (Jeromin et al., 1996); delta receptors probably form ion channels (Zuo et al., 1997), but otherwise, little is known about delta glutamate receptor function.

\section{Developmental regulation of receptor targeting}

Delta and AMPA receptors show different synaptic distribution patterns in each of three main stages in Purkinje cell synaptogenesis, represented in this study by P2 and P5 (stage 1), P10 and P14 (stage 2), and P21 and adult (stage 3). During stage 1 , climbing fibers form most or all of the Purkinje cell synapses; these synapses contain abundant GluR2/3 and GluR2 immunolabeling and yet contain only low immunolabeling for delta $1 / 2$. The presence of substantial immunogold labeling for GluR2 and GluR3 receptor subunits is consistent with physiological studies showing climbing fiber-induced potentials in Purkinje cells in rats as early as P2 (Crépel et al., 1981). Physiological evidence suggests that AMPA/kainate receptors are present in Purkinje cells at $\mathrm{P} 4$ and function similarly to receptors at later ages (P12-P18) (Häusser and Roth, 1997). Delta 2 receptors are present in the embryonic and early postnatal mouse brain (Takayama et al., 1996); the weak signal for mRNA seen in the anterior folia corresponds to the low level of synaptic immunolabeling seen in the present study.

The P10-P14 stage is marked by the widespread abundance of delta and AMPA receptors; delta 1/2, GluR2/3, GluR2, and GluR1 immunolabeling are relatively high in both parallel and climbing fiber synapses. This is a period of great activity in Purkinje cells, marked by the differentiation of the dendrite arborization, proliferation of parallel fiber synapses, formation of climbing fiber/ dendrite synapses, and loss of multiple climbing fiber innervation (Crépel et al., 1981; Mariani and Changeux, 1981; for review, see Altman and Bayer, 1997). Experimental studies using delta 2 knock-out mice (Kashiwabuchi et al., 1995; Kurihara et al., 1997) implicate delta 2 in the formation of both parallel and climbing fiber synapses. Lack of delta 2 protein results in problems in motor coordination, fewer spine synapses on Purkinje cell dendrites evident by P14, an increase in the number of spines without synaptic contacts, prevalence in adults of multiple innervation of Purkinje cells by climbing fibers, as well as impairment of long-term depression. In fact, Kashiwabuchi et al. (1995) suggest that the function of delta 2 may be pleiotropic, so that it plays independent roles in long-term depression of parallel fiber synapses and in the forma- tion of parallel and climbing fiber synapses. This second function could explain the findings of the present study in which delta receptor immunogold labeling was highest in the younger glutamatergic synapses at P10-P14, i.e., parallel fiber- and climbing fiberdendrite synapses versus climbing fiber-somal synapses [preliminary evidence of delta $1 / 2$ in both parallel and climbing fiber synapses at P10 was noted in Zhao et al. (1997) using a preembedding immunoperoxidase method]. In contrast to glutamatergic synapses, no delta receptor immunolabeling was seen in GABAergic synapses. The high level of delta receptor immunolabeling in parallel and climbing fiber synapses in the second postnatal week may help stabilize these synapses, as suggested for parallel fiber synapses by Kurihara et al. (1997). This stabilization also might play a role in the removal of supernumerary innervation by climbing fibers (Kurihara et al., 1997). However, this does not explain the high levels of delta receptor immunolabeling seen in climbing fiber synapses in the second postnatal week. It may be that delta receptors also are stabilizing those climbing fiber synapses that are destined to be retained in the adult. The question will require further study combining delta receptor immunocytochemistry in developing climbing fiber synapses with tracer studies of the innervating climbing fibers to correlate delta receptor expression with innervation pattern.

Our data support a model in which glutamate receptor distribution develops in three stages that correspond to the three stages of Purkinje cell synapse ontogeny shown in Figure 8. The ages selected in this study are representative of these three stages. First, in the early stages of Purkinje cell synaptogenesis, regulation of expression of receptors at synapses would be controlled by the level of receptor protein synthesis. Thus, the high level of immunogold labeling with GluR2 and GluR2/3 antibodies in climbing fiber synapses at P2 and P5 would result from a high level of synthesis of GluR2 and GluR3 subunits (Bergmann et al., 1996), whereas the low level of immunogold labeling for the delta $1 / 2$ antibody in climbing fiber synapses at these ages would result from a low level of synthesis of delta 2 subunits (Takayama et al., 1996). The initial clustering of AMPA receptors at these synapses may be independent of receptor activation or the presence of other kinds of glutamate receptors (O'Brien et al., 1997). However, the role played by specific targeting mechanisms at this stage is unknown and cannot be determined by these data. Second, as synapse input becomes more diverse and abundant, expression 


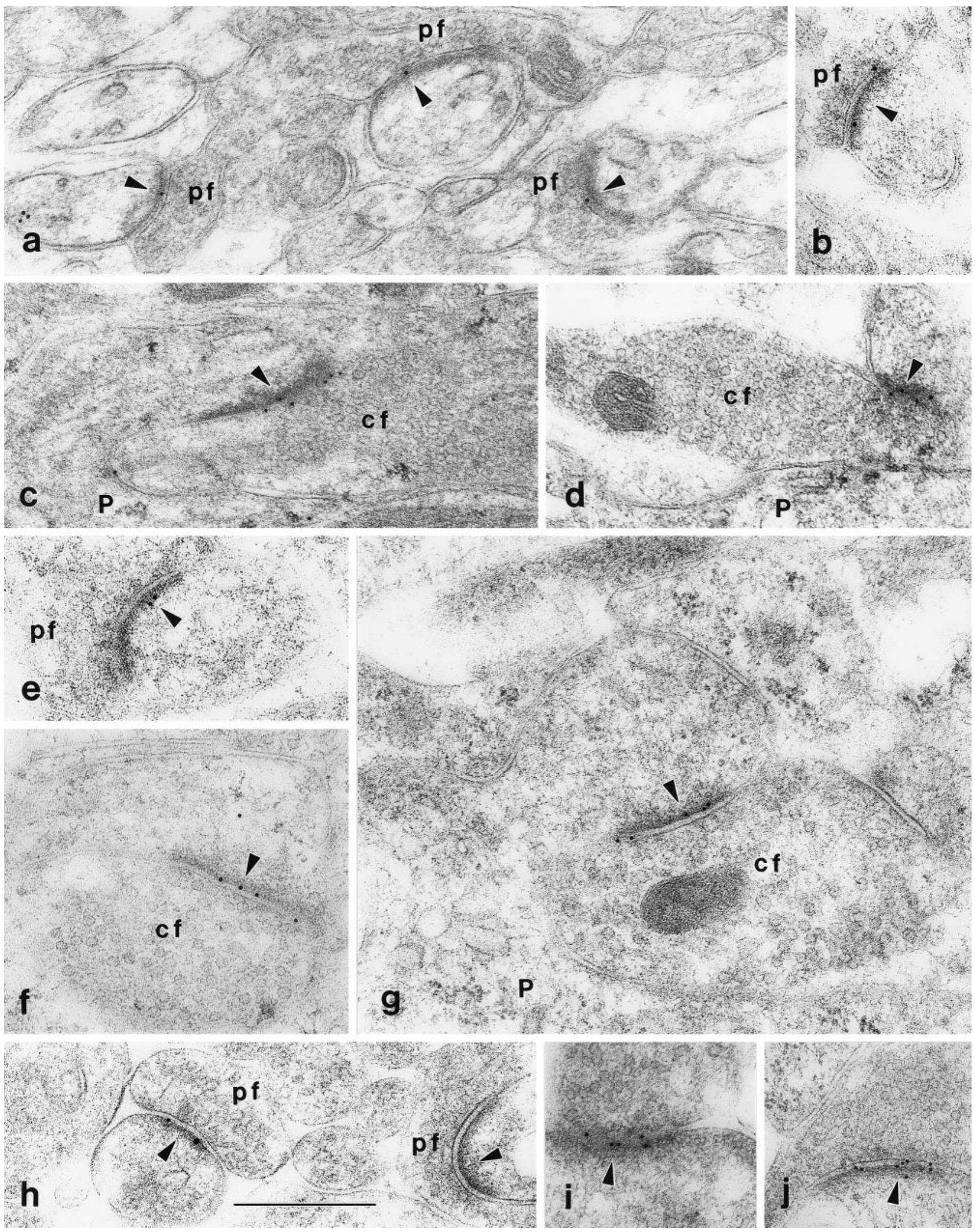

Figure 5. Immunogold labeling for GluR2/3 in the postsynaptic density/membrane (arrowheads) of parallel fiber ( $p f)$ and climbing fiber $(c f)$ synapses on Purkinje cells $(P$; dendrites in $c, f$; somata in $d, g)$ during development. $a, c$, Adult; $b, d, \mathrm{P} 21 ; e, f, \mathrm{P} 14 ; g, h, \mathrm{P} 10 ; i$, P5; and $j, \mathrm{P} 2$. Note the higher labeling of climbing fiber synapses compared with that of parallel fiber synapses. Scale bar, $0.5 \mu \mathrm{m}$. 


\begin{tabular}{|c|c|c|c|c|c|}
\hline & & Number of synapses & $\begin{array}{l}\text { Average length of PSD } \\
(\mathrm{M} \pm \mathrm{SE})\end{array}$ & $\begin{array}{l}\text { Average number of } \\
\text { gold/synapse (range) }\end{array}$ & $\begin{array}{l}\text { Number of gold } / \mu \mathrm{m} \\
(\mathrm{M} \pm \mathrm{SE})\end{array}$ \\
\hline $2 \mathrm{~d}$ & $\mathrm{CF}$ & 67 & $0.28 \pm 0.01$ & $0.91(0-3)$ & $3.39 \pm 0.46$ \\
\hline $5 \mathrm{~d}$ & $\mathrm{CF}$ & 64 & $0.34 \pm 0.01$ & $0.78(0-4)$ & $2.5 \pm 0.42$ \\
\hline \multirow{2}{*}{$10 \mathrm{~d}$} & $\mathrm{PF}$ & 41 & $0.25 \pm 0.01$ & $0.32(0-2)$ & $1.5 \pm 0.43$ \\
\hline & $\mathrm{CF}$ & 38 & $0.35 \pm 0.02$ & $0.95(0-4)$ & $2.6 \pm 0.45$ \\
\hline \multirow{2}{*}{$14 \mathrm{~d}$} & $\mathrm{PF}$ & 24 & $0.24 \pm 0.01$ & $0.25(0-1)$ & $1.02 \pm 0.39$ \\
\hline & $\mathrm{CF}$ & 48 & $0.35 \pm 0.02$ & $1.08(0-4)$ & $3.01 \pm 0.44$ \\
\hline \multirow{2}{*}{$21 \mathrm{~d}$} & $\mathrm{PF}$ & 70 & $0.27 \pm 0.01$ & $0.11(0-2)$ & $0.37 \pm 0.14$ \\
\hline & $\mathrm{CF}$ & 26 & $0.28 \pm 0.02$ & $1.12(0-4)$ & $4.43 \pm 0.78$ \\
\hline \multirow{2}{*}{ Adult } & $\mathrm{PF}$ & 92 & $0.34 \pm 0.01$ & $0.18(0-4)$ & $0.53 \pm 0.15$ \\
\hline & $\mathrm{CF}$ & 23 & $0.30 \pm 0.02$ & $1.43(0-4)$ & $5.46 \pm 0.86$ \\
\hline
\end{tabular}

Abbreviations listed on bottom of Table 2 . The lower number of gold/ $\mu \mathrm{m}$ at PFs versus CFs at P14, P21, and adult was statistically significant $(p<0.01)$.
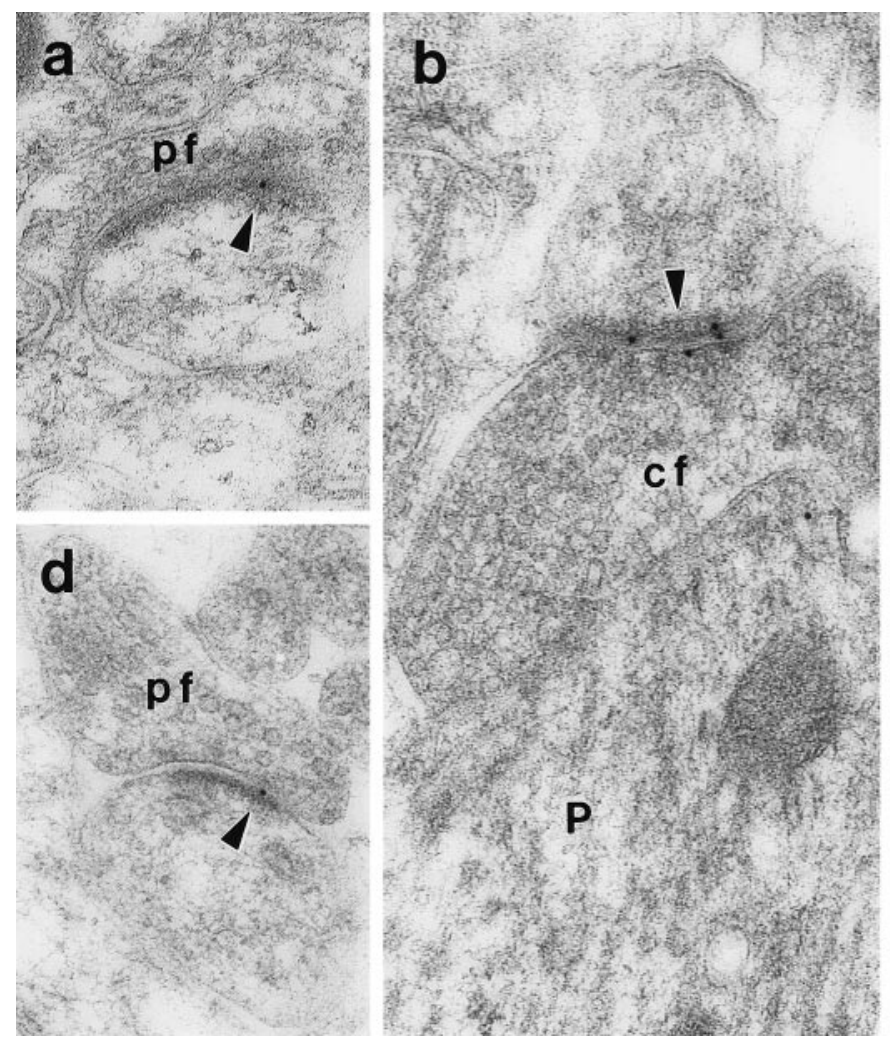

Figure 6. Immunogold labeling for GluR2 in the postsynaptic density/membrane (arrowheads) of parallel fiber ( $p f$ ) and climbing fiber (cf) synapses on Purkinje cells during development. $a$, Adult; $b, \mathrm{P} 21 ; c, d, \mathrm{P} 14$; and $e, \mathrm{P} 2$. Note the higher labeling of climbing fiber synapses compared with that of parallel fiber synapses. $P$, Purkinje cell dendrite. Scale bar, $0.5 \mu \mathrm{m}$.

of glutamate receptors at synapses would be limited to glutamatergic synapses (Craig et al., 1994). At P10 and P14, Purkinje cells form large quantities of delta 2 receptors that then accumulate at the numerous, new parallel and climbing fiber synapses yet are excluded from GABAergic synapses. Finally, as the synapses mature, receptor subtypes would be targeted selectively to different excitatory synapse populations; this would account for the dramatic difference in delta receptor immunolabeling between parallel and climbing fiber synapses at P21 and in the adult.

\section{Mechanisms of synaptic targeting of receptors during synapse development}

These varied distributions of delta receptors are independent of synapse position on the cell. Delta receptor protein, presumably synthesized in the soma [based on mRNA localization during development and in adults (Araki et al., 1993; Lomeli et al., 1993; Takayama et al., 1996)], must bypass many synapses en route to other synapses where it will accumulate. Such a phenomenon must entail some active mechanisms for developmental regulation of targeting.

Glutamate receptor molecules that are synthesized in the Purkinje cell body must somehow be sorted, targeted to the proper synapses, and inserted into the postsynaptic membrane. Differential distribution, as seen with delta 2 , is determined at some point in this process. It is not clear where this occurs, but the two extreme possibilities are that this selective targeting is determined either in the cell body or at the postsynaptic density. In the first case, the sorted receptors would need to be transported 

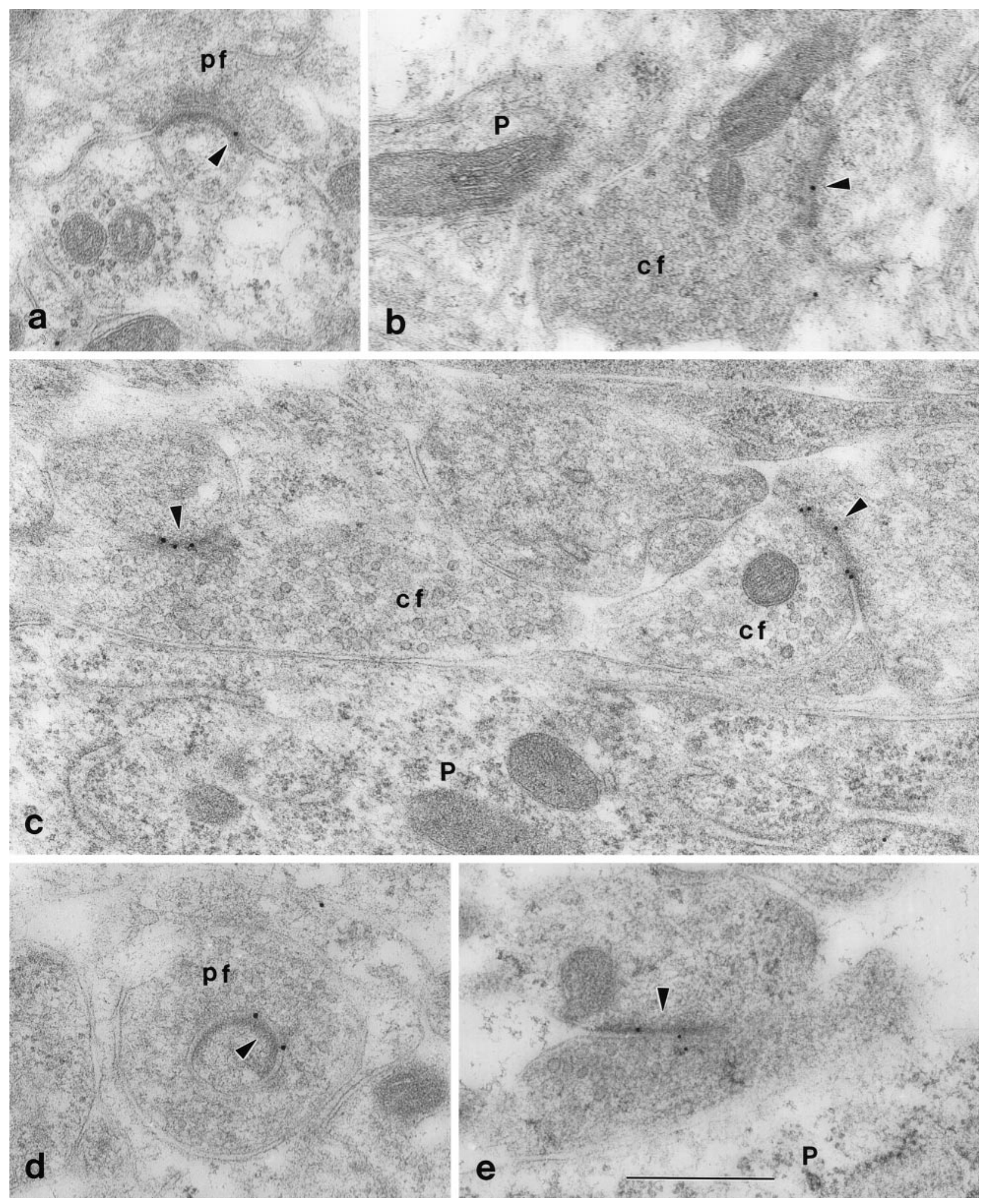

Figure 7. Immunogold labeling for GluR1 in the postsynaptic density/membrane (arrowheads) of parallel fiber ( $p f$ ) and climbing fiber ( $c f$ ) synapses on Purkinje cells during development. $a, b$, Adult; $c, d, \mathrm{P} 10$; and $e, \mathrm{P} 2$. Note the high level of staining at P10. Most synapses at $\mathrm{P} 2$ were not labeled as highly as those in the example shown. $P$, Purkinje cell dendrite $(b)$ and somata $(c, e)$. Scale bar, $0.5 \mu \mathrm{m}$.

separately from the cell body through the dendrite and to the synapses. In the second case, the receptors could be transported indiscriminately throughout the cell body and dendrite, with selection of receptors limited to the postsynaptic membrane of each kind of synapse. In both cases, the sorting presumably involves a selective association of the receptor molecule with other proteins specific to each kind of receptor. Some of these proteins associate with and may anchor the receptors to the 

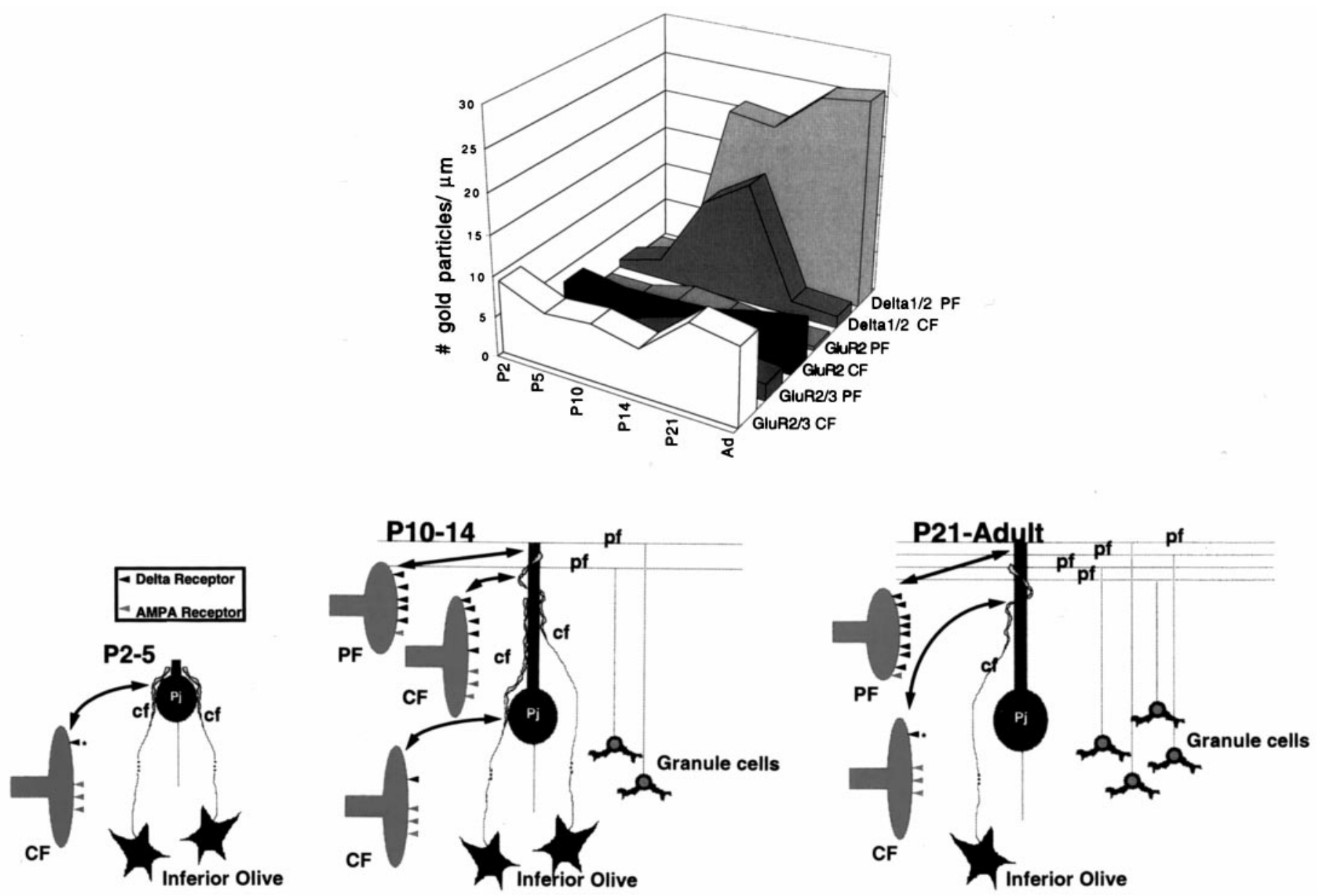

Figure 8. Summary histogram (top) and diagrams (bottom) of development of glutamate receptors at parallel (P10-adult) and climbing (P2-adult) fiber synapses. Histogram, Note especially the peak in immunogold labeling of the delta receptors at P10-P14 in climbing fiber synapses $(C F)$, the peaks of the AMPA receptors at $\mathrm{P} 2-\mathrm{P} 5$, and the inverse patterns of peaks for parallel fiber synapses $(P F)$ and climbing fiber synapses in adults for AMPA versus delta receptors. Diagrams, Climbing fibers $(c f)$ innervate the Purkinje cell $(P j)$ body up to approximately the end of the second postnatal week. By P21, climbing fiber innervation is reduced to a single fiber per Purkinje cell. Climbing fiber synapses on Purkinje cell bodies (early postnatal ages) have many postsynaptic AMPA receptors (based on labeling for GluR2/3 and GluR2) and few delta receptors. Climbing fiber synapses on Purkinje cell dendrites (later postnatal ages to adult) have many AMPA receptors; they have many delta receptors in the second postnatal week but very few from P21 to adult Immunogold labeling for delta receptors at parallel fiber $(p f)$ synapses is always abundant, but less immunogold labeling is seen for AMPA receptors. Labeled terminals are illustrated diagrammatically as postsynaptic spine heads and necks, with the receptors arranged along the surface of the spine head. The number of receptors shown is based approximately on the values of mean number of gold particles per synapse in Tables 1 and 2 and in the Results; it is intended only to show the relative amounts and not to represent actual numbers. The asterisk denotes a level of less than one-half of a receptor per synapse.

postsynaptic membrane and include proteins specific for NMDA (Kornau et al., 1995; Müller et al., 1996; Niethammer et al., 1996; Rao et al., 1998) and AMPA (Dong et al., 1997) receptors. Thus, one possibility is that delta receptors are selectively retained at parallel fiber synapses by some delta receptor-specific protein associated with the postsynaptic density of parallel fiber synapses. Such an anchoring protein might appear in postsynaptic areas of both parallel and climbing fiber synapses beginning at approximately P10 and then be lost from climbing fiber synapses beginning at approximately P21. Further study is needed to identify such proteins and their specific roles in targeting mechanisms.

\section{REFERENCES}

Altman J, Bayer SA (1997) Development of the cerebellar system in relation to its evolution, structure, and functions. New York: CRC.

Araki K, Meguro H, Kushiya E, Takayama C, Inoue Y, Mishina M (1993) Selective expression of the glutamate receptor channel $\delta 2$ subunit in cerebellar Purkinje cells. Biochem Biophys Res Commun 197:1267-1276.
Bahn S, Volk B, Wisden W (1994) Kainate receptor gene expression in the developing rat brain. J Neurosci 14:5525-5547.

Baude A, Molnár E, Latawiec D, McIlhinney RAJ, Somogyi P (1994) Synaptic and nonsynaptic localization of the GluR1 subunit of the AMPA-type excitatory amino acid receptor in the rat cerebellum. J Neurosci 14:2830-2843.

Bergmann M, Fox PA, Grabs D, Post A, Schilling K (1996) Expression and subcellular distribution of glutamate receptor subunits $2 / 3$ in the developing cerebellar cortex. J Neurosci Res 43:78-86.

Bettler B, Boulter J, Hermans-Borgmeyer I, O’Shea-Greenfield A, Deneris ES, Moll C, Borgmeyer U, Hollmann M, Heinemann S (1990) Cloning of a novel glutamate receptor subunit, GluR5: expression in the nervous system. Neuron 5:583-595.

Craig AM, Blackstone CD, Huganir RL, Banker G (1994) Selective clustering of glutamate and $\gamma$-aminobutyric acid receptors opposite terminals releasing the corresponding neurotransmitters. Proc Natl Acad Sci USA 91:12373-12377.

Crépel F, Delhaye-Bouchaud N, Dupont JL (1981) Fate of the multiple innervation of cerebellar Purkinje cells by climbing fibers in immature control, x-irradiated and hypothyroid rats. Dev Brain Res 1:59-71.

Dong H, O'Brien RJ, Fung ET, Lanahan AA, Worley PF, Huganir RL 
(1997) GRIP: a synaptic PDZ domain-containing protein that interacts with AMPA receptors. Nature 386:279-284.

Gallo V, Upson JM, Hayes WP, Vyklicky LJ, Winters CA, Buonanno A (1992) Molecular cloning and developmental analysis of a new glutamate receptor subunit isoform in cerebellum. J Neurosci 12:1010-1023.

Häusser M, Roth A (1997) Dendritic and somatic glutamate receptor channels in rat cerebellar Purkinje cells. J Physiol (Lond) 501:77-95.

Jeromin A, Huganir RL, Linden DJ (1996) Suppression of the glutamate receptor $\delta 2$ subunit produces a specific impairment of cerebellar longterm depression. J Neurophysiol 76:3578-3583.

Kano M, Hashimoto K, Kurihara H, Watanabe M, Inoue Y, Aiba A, Tonegawa S (1997) Persistent multiple climbing fiber innervation of cerebellar Purkinje cells in mice lacking mGluR1. Neuron 18:71-79.

Kashiwabuchi N, Ikeda K, Araki K, Hirano T, Shibuki K, Takayama C, Inoue Y, Kutsuwada T, Yagi T, Kang Y, Aizawa S, Mishina M (1995) Impairment of motor coordination, Purkinje cell synapse formation, and cerebellar long-term depression in GluR $\delta 2$ mutant mice. Cell 8:245-252.

Kornau H-C, Schenker LJ, Kennedy MB, Seeburg PH (1995) Domain interaction between NMDA receptor subunits and the postsynaptic density protein PSD-95. Science 269:1737-1740.

Kurihara H, Hashimoto K, Kano M, Takayama C, Sakimura K, Mishina M, Inoue Y, Watanabe M (1997) Impaired parallel fiber-Purkinje cell synapse stabilization during cerebellar development of mutant mice lacking the glutamate receptor $\delta 2$ subunit. J Neurosci 17:9613-9623.

Landsend AS, Amiry-Moghaddam M, Matsubara A, Bergersen L, Usami S, Wenthold RJ, Ottersen OP (1997) Differential localization of $\delta$ glutamate receptors in the rat cerebellum: coexpression with AMPA receptors in parallel fiber-spine synapses and absence from climbing fiber-spine synapses. J Neurosci 17:834-842.

Laurie DJ, Seeburg PH (1994) Regional and developmental heterogeneity in splicing of the rat brain NMDAR1 mRNA. J Neurosci 14:3180-3194.

Levenes C, Daniel H, Jaillard D, Conquet F, Crépel F (1997) Incomplete regression of multiple climbing fibre innervation of cerebellar Purkinje cells in mGluR1 mutant mice. NeuroReport 8:571-574.

Linden DJ (1994) Long-term depression in the mammalian brain. Neuron 12:457-472.

Llinás RR, Walton KD (1998) Cerebellum. In: The synaptic organization of the brain, Fourth Edition (GM Shepherd, ed), pp 255-288. New York: Oxford UP.

Lomeli H, Sprengel R, Laurie DJ, Köhr G, Herb A, Seeburg PH, Wisden W (1993) The rat delta-1 and delta-2 subunits extend the excitatory amino acid receptor family. FEBS Lett 315:318-322.

Mariani J, Changeux J-P (1981) Ontogenesis of olivocerebellar relationships. I. Studies by intracellular recordings of the multiple innervation of Purkinje cells by climbing fibers in the developing rat cerebellum. J Neurosci 1:696-702.

Martin LJ, Blackstone CD, Levey AI, Huganir RL, Price DL (1993) AMPA glutamate receptor subunits are differentially distributed in rat brain. Neuroscience 53:327-358.

Matsubara A, Laake JH, Davanger S, Usami S, Ottersen OP (1996) Organization of AMPA receptor subunits at a glutamate synapse: a quantitative immunogold analysis of hair cell synapses in the rat organ of Corti. J Neurosci 16:4457-4467.

Mayat E, Petralia RS, Wang Y-X, Wenthold RJ (1995) Immunoprecipitation, immunoblotting, and immunocytochemistry studies suggest that glutamate receptor $\delta$ subunits form novel postsynaptic receptor complexes. J Neurosci 15:2533-2546.

Mugnaini E (1972) The histology and cytology of the cerebellar cortex. In: The comparative anatomy and histology of the cerebellum: the human cerebellum, cerebellar connections, and cerebellar cortex (Larsell O, Jansen J, eds), pp 201-251. Minneapolis: University of Minnesota.

Müller BM, Kistner U, Kindler S, Chung WJ, Kuhlendahl S, Fenster SD, Lau L-F, Veh RW, Huganir RL, Gundelfinger ED, Garner CC (1996) SAP102, a novel postsynaptic protein that interacts with NMDA receptor complexes in vivo. Neuron 17:255-265.

Niethammer M, Kim E, Sheng M (1996) Interaction between the C-terminus of NMDA receptor subunits and multiple members of the PSD-95 family of membrane-associated guanylate kinases. J Neurosci 16:2157-2163.

Nusser Z, Mulvihill E, Streit P, Somogyi P (1994) Subsynaptic segregation of metabotropic and ionotropic glutamate receptors as revealed by immunogold localization. Neuroscience 61:421-427.

Nusser Z, Sieghart W, Somogyi P (1998) Segregation of different
$\mathrm{GABA}_{\mathrm{A}}$ receptors to synaptic and extrasynaptic membranes of cerebellar granule cells. J Neurosci 18:1693-1703.

O'Brien RJ, Mammen AL, Blackshaw S, Ehlers MD, Rothstein JD, Huganir RL (1997) The development of excitatory synapses in cultured spinal neurons. J Neurosci 17:7339-7350.

Palay S, Chan-Palay V (1974) Cerebellar cortex: cytology and organization. New York: Springer.

Pellegrini-Giampietro DE, Bennett MVL, Zukin RS (1991) Differential expression of three glutamate receptor genes in developing rat brain: an in situ hybridization study. Proc Natl Acad Sci USA 88:4157-4161.

Petralia RS, Wenthold RJ (1992) Light and electron immunocytochemical localization of AMPA-selective glutamate receptors in the rat brain. J Comp Neurol 318:329-354.

Petralia RS, Wenthold RJ (1998) Glutamate receptor antibodies: production and immunocytochemistry. In: Receptor localization: laboratory methods and procedures (Ariano MA, ed), pp 46-74. New York: Wiley.

Petralia RS, Yokotani N, Wenthold RJ (1994) Light and electron microscope distribution of the NMDA receptor subunit NMDAR1 in the rat nervous system using a selective anti-peptide antibody. J Neurosci 14:667-696.

Petralia RS, Wang Y-X, Mayat E, Wenthold RJ (1997) Glutamate receptor subunit 2-selective antibody shows a differential distribution of calcium-impermeable AMPA receptors among populations of neurons. J Comp Neurol 385:456-476.

Phend KD, Rustioni A, Weinberg RJ (1995) An osmium-free method of Epon embedment that preserves both ultrastructure and antigenicity for post-embedding immunocytochemistry. J Histochem Cytochem 43:283-292.

Popratiloff A, Weinberg RJ, Rustioni A (1996) AMPA receptor subunits underlying terminals of fine-caliber primary afferent fibers. J Neurosci 16:3363-3372.

Rabacchi S, Bailly Y, Delhaye-Bouchaud N, Mariani J (1992) Involvement of the $N$-methyl-D-aspartate (NMDA) receptor in synapse elimination during cerebellar development. Science 256:1823-1825.

Rao A, Kim E, Sheng M, Craig AM (1998) Heterogeneity in the molecular composition of excitatory postsynaptic sites during development of hippocampal neurons in culture. J Neurosci 18:1217-1229.

Rubio ME, Wenthold RJ (1997) Glutamate receptors are selectively targeted to postsynaptic sites in neurons. Neuron 18:939-950.

Siegel SJ, Brose N, Janssen WG, Gasic GP, Jahn R, Heinemann SF, Morrison JH (1994) Regional, cellular, and ultrastructural distribution of $N$-methyl-D-aspartate receptor subunit 1 in monkey hippocampus. Proc Natl Acad Sci USA 91:564-568.

Takayama C, Nakagawa S, Watanabe M, Mishina M, Inoue Y (1996) Developmental changes in expression and distribution of the glutamate receptor channel $\delta 2$ subunit according to the Purkinje cell maturation. Dev Brain Res 92:147-155.

Wang B-L, Larsson L-I (1985) Simultaneous demonstration of multiple antigens by indirect immunofluorescence or immunogold staining. Novel light and electron microscopical double and triple staining method employing primary antibodies from the same species. Histochemistry 83:47-56.

Wang Y-X, Wenthold RJ, Ottersen OP, Petralia RS (1998) Endbulb synapses in the anteroventral cochlear nucleus express a specific subset of AMPA-type glutamate receptor subunits. J Neurosci 18:1148-1160.

Wenthold RJ, Zempel JM, Parakkal MH, Reeks KA, Altschuler RA (1986) Immunocytochemical localization of GABA in the cochlear nucleus of the guinea pig. Brain Res 380:7-18.

Wenthold RJ, Yokotani N, Doi K, Wada K (1992) Immunochemical characterization of the non-NMDA glutamate receptor subunit-specific antibodies: evidence for a hetero-oligomeric structure in rat brain. J Biol Chem 267:501-507.

Wenthold RJ, Wang Y-X, Petralia RS, Rubio ME (1997) Distribution and targeting of glutamate receptors in the cochlear nucleus. In: Acoustical signal processing in the central auditory system (Syka J, ed), pp 93-107. New York: Plenum.

Yuzaki M, Forrest D, Verselis LM, Sun SC, Curran T, Connor JA (1996) Functional NMDA receptors are transiently active and support the survival of Purkinje cells in culture. J Neurosci 16:4651-4661.

Zhao H-M, Wenthold RJ, Wang Y-X, Petralia RS (1997) Delta glutamate receptors are differentially distributed at parallel and climbing fiber synapses on Purkinje cells. J Neurochem 68:1041-1052.

Zuo J, De Jager PL, Takahashi KA, Jiang W, Linden DJ, Heintz N (1997) Neurodegeneration in Lurcher mice caused by mutation in $\delta 2$ glutamate receptor gene. Nature 388:769-773. 